\title{
Nutrient Dynamics in an Avicennia marina (Forsk.) Vierh., Mangrove Forest in Vamleshwar, Gujarat, India
}

\author{
Isaiah J. NIRMAL KUMAR ${ }^{1}$, Poliyaparambil Ravi SAJISH ${ }^{1}$, Rita \\ NIRMAL KUMAR ${ }^{2}$, George BASIL', Viyol SHAILENDRA ${ }^{1}$ \\ ${ }^{1}$ Institute of Science and Technology for Advanced Studies and Research (ISTAR), P. G. Department of Environmental \\ Science and Technology,Vallabb Vidya Nagar, Gujarat-388120, India; istares2005@yahoo.com \\ ${ }^{2}$ N. V. Patel College of Pure and Applied Sciences, Vallabh Vidya Nagar, Department of Biological Science \\ and Environmental Science, Gujarat-388 120,India;nvpas2009@gmail.com
}

\begin{abstract}
The study was carried out to determine the nutrient budget of plants, sediments and nutrient dynamics in an Avicennia marina (Forsk.) Vierh., dominated forest in Vamleshwar near Narmada estuary, West Coast of Gujarat for a period of one year from November 2008 to October 2009. The average tree height of the mangrove is 1.5 to $2 \mathrm{~m}$ without much vertical stratification. Allometric methodology was used to measure the biomass, and yield a figure of $86.47 \mathrm{t} \mathrm{ha}^{-1}$ and the litter fall rate amounted to $2.9 \mathrm{t} \mathrm{ha}^{-1}$. Nutrient stocks of $\mathrm{N}$, P and $\mathrm{K}$ in this mangrove were $137.05,14.38$ and $241.29 \mathrm{~kg} \mathrm{ha}^{-1}$, with an annual accumulation of $55.74,12.38$ and $83.94 \mathrm{~kg} \mathrm{ha}^{-1}$, and an annual return of 51.30, 10.83 and $13.52 \mathrm{~kg} \mathrm{ha}^{-1}$, respectively, in the form of litter. The annual uptake for $\mathrm{N}, \mathrm{P}$ and $\mathrm{K}$ were $61.04,14.28$ and 97.46 $\mathrm{kg} \mathrm{ha}^{-1}$, and turnover rates of N, P and K were estimated at 3, 6 and 14 years, respectively, for the study period. Flow coefficients, which reveal the dynamic processes of nutrients between mangrove plants and sediments, are also explained. The present study concluded that the $A$. marina dominated mangrove plantation is more efficient in nutrient use and conservation.
\end{abstract}

Keywords: annual accumulation, annual return, annual uptake, flow coefficient, nutrient stocks

\section{Introduction}

Mangroves are unique intertidal woody communities, common in tropical and subtropical coastlines. They are important not only in protecting coasts from erosion by storm tides, but also maintaining the diversity of coastal ecosystems by contributing quantities of food/nutrients and providing favorable habitats for other plants and animals (Tomlinson, 1986). Nitrogen, phosphorus and potassium are elements essential to a variety of biological and chemical processes, both at the organism level (e.g. somatic growth, reproduction) and on the scale of ecosystems. Nutrients are made available to most forests from precipitation and dry atmospheric fallout and from the weathering of rocks and soil minerals. With little surface drainage entering from the surrounding environment, mangrove forests depend mostly on the nutrients from sediment (released from decomposed organisms) which may receive replenishment of nutrient supplies from periodic flooding. Several studies have indicated that mangroves are nutrient limited (mainly N and P) (Akamatsu et al., 2009; Boto and Wellington, 1983; Islam et al., 2008; Uchiyama et al., 2000).

Frugal use of nutrients has been hypothesized for mangrove plants, and a nutrient transfer prior to fall off senescent leaves has been well documented (Erskine et al., 2006; Kimmins, 2004; Schwartz et al., 2000; Woodwell et al., 1975). Progress has been made on the contribution of mangrove detritus to adjacent near-shore areas, but comparatively few data are available on nutrient pool transformations and flux within mangrove forests (Alongi, 1989; Boto, 1992). Nevertheless, nutrient dynamics have been studied in estuaries, salt marshes and tropical mangrove ecosystems (Gong and Ong, 1990; Wiebe, 1987) although relatively less in subtropical mangroves (Lin et al., 1987; Schwendenmann et al., 2006; Shaiful, 1987). An excellent review has presented on comprehensive picture of nitrogen and phosphorus cycling in mangrove ecosystems, including the distribution, transformation and fluxes of various nitrogenous and phosphorus species in mangrove sediments and in tidal creek waters, with particular reference to the Australian mangroves by Alongi et al. (2005). In the present study, we examined the biological cycling and dynamics of N, P and K elements between mangrove plants and the sediments in Vamleshwar mangrove forest, Near Narmada Estuary, West Coast of Gujarat, India. Moreover, various works have been carried out by Nirmal Kumar et al. (2010a; 2010b; 2011) in the field of fuel wood properties, seasonal changes of bio elements and assessment of carbon stock in the Teak and Butea forest ecosystem, Western India, Rajasthan. Quantification of nutrients and decomposition of litter have been studied in Teak and Butea forests of Rajasthan, Western India by Nirmal Kumar et al. (2010c; 2009a; 2009b). 
52

\section{Materials and methods}

\section{Study site}

The study was conducted at $A$. marina plantation, Vamleshwar, Narmada estuary covering an area of 100 ha (GEC ) from November 2008 to October 2009, which is located at a latitude of $21^{\circ} 30^{\prime} 11.55^{\prime \prime} \mathrm{N}$ and longitude of $72^{\circ} 43^{\prime} 53.68^{\prime \prime} \mathrm{E} 45 \mathrm{~km}$ to west of Ankleshwar, Gujarat, India towards Arabian Sea (Fig. 1). The study area has various natural resources, vast array of biological diversity and coastal and riverine fishing activities. The average tree height is $1.5-2 \mathrm{~m}$ with no vertical stratification. The climate of this area is dry, with mean annual relative humidity of $46.18 \%$. The mean annual air temperature is $30.42^{\circ} \mathrm{C}$, with minimum and maximum values at $19.2^{\circ} \mathrm{C}$ (in January) and $38.7^{\circ} \mathrm{C}$ (in June), respectively. Annual precipitation is $800 \mathrm{~mm}$, and the rainy season is from June to September. The mangrove area is inundated by an incoming tide twice a day and the tidal range is about $2.1 \mathrm{~m}$. The sediment is darkly coloured and gives off an odour of $\mathrm{H}_{2} \mathrm{~S}$, suggesting an obviously anaerobic condition in the soil.

\section{Estimation of biomass annual growth}

Ten quadrats each of $10 \mathrm{~m} \times 10 \mathrm{~m}$, were laid within the mangrove forest to determine the stand biomass. The $\mathrm{dbh}$ and height of each tree were recorded. The biomass

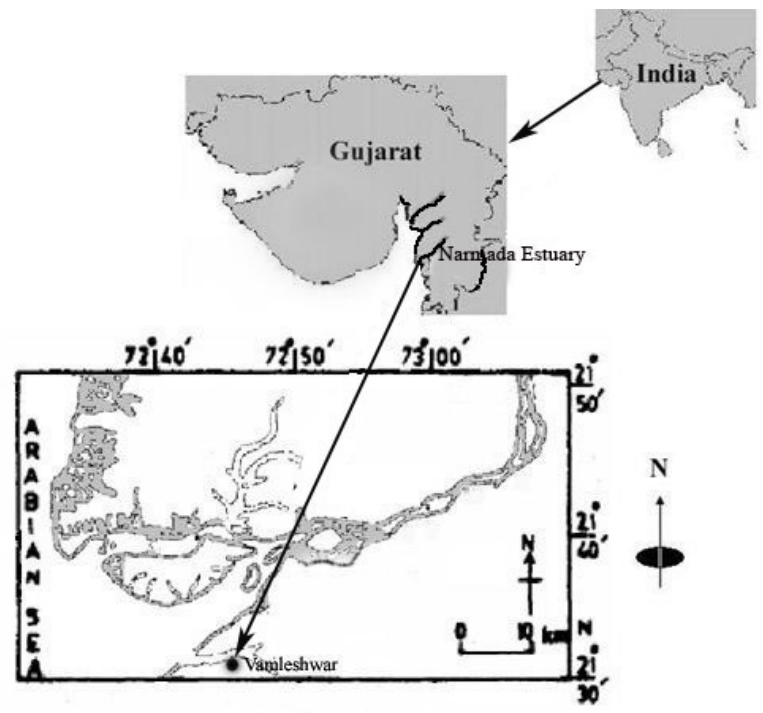

Fig. 1. Location of the study area

of the plant community was estimated by the allometric equation formulated from the harvested data (Dittmar $e t$ al., 2006; Komiyama et al., 2008):

$$
\mathrm{Y}=a+b \mathrm{X}
$$

where, $Y$ is the biomass of the component, $a$ and $b$ are the constants, $\mathrm{X}$ is the $\mathrm{DBH}$.

Thirty trees of $A$. marina were randomly chosen from the quadrats. The individual tree was harvested and the aerial parts were separated into stem, branch and leaf. The fresh weights of these components were recorded. Subsamples were dried at $80^{\circ} \mathrm{C}$ to constant weight.
A tree of $A$. marina was harvested for growth ring analysis. Stem discs were cut at the base, 0.2, 0.5, 1.0, 1.3 and $1.8 \mathrm{~m}$. All lateral growth measurements are in terms of south-north direction. The average and annual growth of timber volume can be calculated following the traditional forestry method (Anuchin, 1970), which has been applied to mangrove forests (Lin and Zheng, 1986). The annual growth rate of timber volume was defined as the annual net increment of timber volume per year divided by the total timber volume. This rate is 0.1482 for $A$. marina.

\section{Sampling of sediments, plants and chemical analyses}

In the study area, surface soil samples $(0-30 \mathrm{~cm})$ were taken at regular intervals from landward to seaward region. Triplicate samples were collected, air dried, passed through a $2 \mathrm{~mm}$ sieve and then analysed for nutrients. Meanwhile, at the same interval where sediment samples were collected, mature leaves of $A$. marina were taken. At three points (landward, middle and seaward of the mangrove), triplicate samples of root and stem were collected, respectively. Separated parts of plant samples were oven dried at $80^{\circ} \mathrm{C}$ and then ground into powder. Total Nitrogen was determined by micro-Kjeldahl digestion followed by steam distillation. Total Phosphorous was determined colorimetrically by the molybdate method (Murphy and Riley, 1962) and total $\mathrm{K}$ by flame photometry. $\mathrm{NH}_{4}^{+}$, $\mathrm{NO}_{2}$ and $\mathrm{NO}_{3}-\mathrm{N}$ (extracted with $2 \mathrm{~N} \mathrm{KCl}$ at $1: 4$ ratio followed by distillation), available P (Prasad, 2005) and extractable $\mathrm{K}$ (extracted with $1 \mathrm{M}$ ammonium acetate $(\mathrm{pH} 4)$ at 1:5 soil: water ratio) were also measured for soil samples. Stock and allocation of nutrients in different components were calculated by multiplying nutrient concentration values with corresponding biomass. Mean values were used in the calculation.

Litter production, annual return, accumulation, uptake of nutrients, and turnover rate

Assuming annual net leaf production was zero, i.e. annual leaf growth equaled annual leaf litter fall (Bala Krishna Prasad and Ramanathan, 2008), annual accumulation was actually the nutrients accumulated in the woody components and was calculated using the nutrient contents multiplied by the respective net growth. Annual uptake is the sum of annual accumulation and annual return of nutrients (Duvigneaud and Denaever-De Smet, 1970). Annual uptake indicates the need for nutrients by mangrove plants. Turnover rate is the ratio of the stock of an element in biomass divided by the return of the element in yearly litter fall.

\section{Results and discussion}

\section{Biomass, stock and allocation of nutrients}

Nutrient concentration varied from tissue to tissue (Tab. 1). Highest $\mathrm{N}$ concentration was found in the leaf tissues but lowest in the roots, while $\mathrm{P}$ and $\mathrm{K}$ were rich- 
est in the roots but lowest in the stems. Nutrient levels in litter components have been less studied than in fresh tissue (YiMing and Sternberg, 2007; Woodroffe et al., 1988; Twilley, 1986). No data were available for $A$. marina litter nutrient contents. For Kandelia, Lin and Zheng (1986) measured N, P and K contents in litter accounts for 1.79, 0.14 and $0.66 \%$, respectively. As compared with these values, litter nutrient levels in the Vamleshwar mangrove were significantly lower with $\mathrm{N}-0.257 \%$; $-0.092 \%$ and $\mathrm{K}-0.456 \%$.

Tab. 1. Concentrations of nutrients in different components of Avicennia marina

\begin{tabular}{cccc}
\hline Component & $\mathrm{N}$ & $\mathrm{P}$ & $\mathrm{K}$ \\
\hline Stem & $0.473 \pm 0.183$ & $0.076 \pm 0.032$ & $0.372 \pm 0.051$ \\
Leaf & $1.172 \pm 0.219$ & $0.133 \pm 0.011$ & $0.421 \pm 0.019$ \\
Root & $0.438 \pm 0.293$ & $0.166 \pm 0.019$ & $1.480 \pm 0.138$ \\
Average of above & 0.694 & 0.125 & 0.758 \\
Litter & $0.257 \pm 0.03$ & $0.092 \pm .001$ & $0.456 \pm .006$ \\
\hline
\end{tabular}

Values are mean $(\%) \pm \mathrm{SD}(\mathrm{n}=30)$

The biomass of this mangrove community was estimated to $86.47 \mathrm{t} \mathrm{ha}^{-1}$. The total nutrient stocks for $\mathrm{N}, \mathrm{P}$ and $\mathrm{K}$ were $437.05,90.38$ and $588.29 \mathrm{~kg} \mathrm{ha}^{-1}$ (Tab. 2). Allocation of nutrients was affected most heavily, of course, by the biomass of plant tissues. It was also affected by the nutrient content of plant components in greatest abundance. Leaves, for instance, appeared to have the lowest nutrient stocks although they contained the highest amount of $\mathrm{N}$. On the whole, the elemental stocks followed the order of $\mathrm{K}>\mathrm{N}>\mathrm{P}$.

Tab. 2. Stock and allocation of nutrients in Avicennia marina mangrove

\begin{tabular}{ccccc}
\hline Component & Biomass & $\mathrm{N}$ & $\mathrm{P}$ & $\mathrm{K}$ \\
\hline Stem & 57.45 & 271.85 & 44.04 & 213.74 \\
Leaf & 5.20 & 60.95 & 6.89 & 21.92 \\
Root & 23.82 & 104.25 & 39.45 & 352.63 \\
Total & 86.47 & 437.05 & 90.38 & 588.29 \\
\hline
\end{tabular}

Biomass values are in $\mathrm{t}$ dry wt ha ${ }^{-1}$, and other values are in $\mathrm{kg} \mathrm{ha}^{-1}$

Nutrient concentrations in mangrove plant tissues are results of long-term adaptations to the nutrient availability in the surrounding environments. As the nutrient concentrations of leaf tissue reflected the soil nutrient status which differed significantly, the leaf N, P and $\mathrm{K}$ contents of the plant species would vary from mangroves to mangroves (Carlos et al., 2007; Tam et al., 1995). However, Chen and Lindley (1983) reported, after working on the nutrient characteristics of several estuarine mangrove forests along north-east Hainan coasts, that the correlation coefficients between leaf and soil nutrients were fairly low or even negative, i.e. -0.33 for $\mathrm{N},-0.55$ for $\mathrm{P}$ and -0.43 for $\mathrm{K}$. These revealed that the nutrient levels in plant tissues were not determined much by the nutrient abundance in the soil. Mangrove plants can selectively absorb what they need from the sediments.

\section{Annual growth and accumulation of nutrients}

The annual nutrient accumulation and partitioning have been presented in Tab. 3. The total annual accumulation for N, P and $\mathrm{K}$ amounted to 55.74, 12.38 and 83.94 $\mathrm{kg} \mathrm{ha}^{-1}$, respectively. $\mathrm{N}$ seemed to accumulate mainly in stems $(72.3 \%)$, while $\mathrm{K}$ mainly in roots $(62.3 \%) . \mathrm{K}$ accumulation in plant was many folds greater than $\mathrm{P}$ and $\mathrm{N}$ (1.5-5.8 times).

Tab. 3. The annual accumulation of nutrients in $A$. marina mangrove

\begin{tabular}{ccccc}
\hline Components & Growth & $\mathrm{N}$ & $\mathrm{P}$ & $\mathrm{K}$ \\
\hline Stem & 4965 & 40.29 & 6.53 & 31.68 \\
Root & 4024 & 15.45 & 5.85 & 52.26 \\
Total & 8989 & 55.74 & 12.38 & 83.94 \\
\hline
\end{tabular}

All values are in $\mathrm{kg} \mathrm{ha}^{-1}$

\section{Annual nutrient uptake}

The total uptakes of N, P and K were 61.04, 14.28 and $97.46 \mathrm{~kg} \mathrm{ha}^{-1}$ (Tab. 4), with return/accumulation ratios of $0.92,0.87$ and 0.16 , respectively. The $\mathrm{N}$ and $\mathrm{P}$ ratios were about 1.0, but the $\mathrm{K}$ ratio was much lower, suggesting that dynamic $\mathrm{N}$ and $\mathrm{P}$ processes were near equilibrium, and $\mathrm{K}$ was strongly consumed by the plants.

Tab. 4. Annual uptake of nutrients in A. marina mangrove

\begin{tabular}{cccc}
\hline & $\mathrm{N}$ & $\mathrm{P}$ & $\mathrm{K}$ \\
\hline Accumulation $\left(\mathrm{kg} \mathrm{ha}^{-1}\right)$ & 55.74 & 12.38 & 83.94 \\
Return $\left(\mathrm{kg} \mathrm{ha}^{-1}\right)$ & 51.30 & 10.83 & 13.52 \\
Uptake $\left(\mathrm{kg} \mathrm{ha}^{-1}\right)$ & 61.04 & 14.28 & 97.46 \\
Return/Accumulation ratio & 0.92 & 0.87 & 0.16 \\
\hline
\end{tabular}

\section{Turnover rate}

The turnover rates of $\mathrm{N}, \mathrm{P}$ and $\mathrm{K}$ in this mangrove were calculated to be 3, 6 and 14 years, respectively, using the litter values of 2008-2009 and comparisons of turnover rates among mangroves are given in Tab. 5. Turnover rate may correlate to the age of the forest. Gong and Ong (1990) revealed that the increased age, the forest has a longer nutrient turnover period before it reaches maturity. Turnover rate is affected by biomass, litter production and the

Tab. 5. Turnover rates of $\mathrm{N}, \mathrm{P}$ and $\mathrm{K}$ in some mangroves

\begin{tabular}{|c|c|c|c|c|c|c|}
\hline $\begin{array}{l}\text { Forest } \\
\text { type }\end{array}$ & $\begin{array}{c}\text { Age } \\
\text { (years) }\end{array}$ & Location & $\begin{array}{c}\mathrm{N} \\
\text { (years) }\end{array}$ & $\begin{array}{c}\mathrm{P} \\
\text { (years) }\end{array}$ & $\begin{array}{c}\mathrm{K} \\
\text { (years) }\end{array}$ & Sources \\
\hline $\begin{array}{c}\text { Rhizophora } \\
\text { mangle }\end{array}$ & & Panama & - & 23 & 8 & $\begin{array}{l}\text { Golley } \\
\text { et al. } \\
(1975)\end{array}$ \\
\hline \multirow{3}{*}{ R. apiculata } & $1-10$ & Matang & 12.29 & 7.12 & 4.95 & \multirow{3}{*}{$\begin{array}{c}\text { Gong } \\
\text { and Ong } \\
(1990)\end{array}$} \\
\hline & $11-20$ & Malaysia & 19.46 & 8.15 & 10.43 & \\
\hline & $21-30$ & & 30.81 & 10.71 & 10.45 & \\
\hline $\begin{array}{c}\text { Avicennia } \\
\text { marina }\end{array}$ & $1-10$ & $\begin{array}{l}\text { Vamleshwar, } \\
\text { Gujarat, } \\
\text { India }\end{array}$ & 3 & 6 & 14 & $\begin{array}{l}\text { Present } \\
\text { study }\end{array}$ \\
\hline
\end{tabular}


54

nutrient contents of both components. Biomass increases as the forest grows, in contrast, litter fall is, instead, controlled more by physical factors such as temperature and precipitation and does not necessarily increase with age. All factors which influence the litter fall can also change the turnover rate value.

\section{Sediment nutrient pool}

The nutrient status of mangrove sediments in Vamleshwar is presented in Tab. 6. The soil $\mathrm{N}$ and P levels declined gradually with the distance away from the land, but $\mathrm{K}$ remained relatively constant. Seasonal variations were found to exist for $\mathrm{K}$, but not very clear for $\mathrm{P}$ and $\mathrm{N}$ (Wong et al., 1995). Mean concentrations of N, P and K were 0.154 , 0.169 and $1.72 \%$, respectively, well within the reported ranges $(0.018-0.4 \%$ for $\mathrm{N}, 0.004-0.160 \%$ for $\mathrm{P}$ and 0.48 $5.02 \%$ for $\mathrm{K}$ ). Taking $0-30 \mathrm{~cm}$ surface soil into consideration (mainly because most of the mangrove roots are distributed in this layer), the total nutrient stocks of N, P and $\mathrm{K}$ in the sediments were $3883.4,3209.8$ and 36073.5 $\mathrm{kg} \mathrm{ha}^{-1}$, i.e. $6.3,27.7$ and 47.3 times as much stock as in the plant community. These were undoubtedly the large potential nutrient pools for mangrove plants. The large quantities of nutrients in the sediments were not readily available to plants because most of them are refractory. Only $4.04 \%$ of the total $\mathrm{N}$ exists in inorganic form. $5.42 \%$ of the total $\mathrm{P}$ and $1.36 \%$ of the total $\mathrm{K}$ are extractable.

Tab. 6. The nutrient status of mangrove soils $(0-30 \mathrm{~cm})$ in $A$. marina mangrove

\begin{tabular}{cc}
\hline Nutrients & Amounts \\
\hline Total $\mathrm{N}(\%)$ & $0.154 \pm 0.001$ \\
$\mathrm{NH}_{4}^{+}-\mathrm{N}\left(\mathrm{kg} \mathrm{ha}^{-1}\right)$ & $157.17 \pm 2.47$ \\
$\mathrm{NO}_{3}^{-}-\mathrm{N}\left(\mathrm{kg} \mathrm{ha}^{1}\right)$ & $\mathrm{ND}$ \\
\hline Total $\mathrm{P}(\%)$ & $0.163 \pm .018$ \\
$\mathrm{PO}_{4}^{3-}-\mathrm{P}\left(\mathrm{kg} \mathrm{ha}^{-1}\right)$ & $173.97 \pm 0.21$ \\
\hline Total K $(\%)$ & $1.72 \pm 0.27$ \\
\hline Ext. $\mathrm{K}\left(\mathrm{kg} \mathrm{ha}^{-1}\right)$ & $490.60 \pm 17.38$ \\
\hline Total $\mathrm{N}$ pool $\left(\mathrm{kg} \mathrm{ha}^{-1}\right)$ & 3883.4 \\
\hline Total $\mathrm{P}$ pool $\left(\mathrm{kg} \mathrm{ha}^{-1}\right)$ & 3209.8 \\
\hline Total K pool $\left(\mathrm{kg} \mathrm{ha}^{-1}\right)$ & 36073.5 \\
\hline
\end{tabular}

Values are mean \pm SD. ND: Not detected

\section{Flow coefficients}

Nutrients are absorbed from the soil, part of which is retained in the plant tissues as the growth of biomass, and parts are returned to the soil via litter fall to join another cycle. These soil-plant-soil nutrient flow processes can be depicted with absorption coefficient (AC), utilization coefficient (UC) by Chen and Lindley (1983) and cycling coefficient (CC) by Larcher (1983). Flow coefficients of nutrients in the Vamleshwar mangroves are presented in Tab. 7. The $\mathrm{N}$ absorption coefficient (0.027) was about three times as much as $\mathrm{P}$, and 7 times as high as K. However, utilization coefficient does not vary significantly. Cy-
Tab. 7. Flow coefficients of nutrients in $A$. marina mangrove

\begin{tabular}{ccccccc}
\hline & \multicolumn{3}{c}{ Avicennia marina } & \multicolumn{3}{c}{ Kandelia candel } \\
\cline { 2 - 7 } & $\mathrm{N}$ & $\mathrm{P}$ & $\mathrm{K}$ & $\mathrm{N}$ & $\mathrm{P}$ & $\mathrm{K}$ \\
\hline $\mathrm{AC}^{\mathrm{a}}$ & 0.022 & 0.008 & 0.003 & 0.027 & 0.019 & 0.205 \\
$\mathrm{UC}^{\mathrm{b}}$ & 0.242 & 0.268 & 0.174 & 0.228 & 0.194 & 0.002 \\
$\mathrm{CC}^{\mathrm{c}}$ & 0.286 & 0.108 & 0.039 & 0.607 & 0.498 & 0.544 \\
\hline Sources & \multicolumn{3}{c}{ Present study } & \multicolumn{3}{c}{ Lin et al. $(1987)$} \\
\hline
\end{tabular}

${ }^{\mathrm{a} A C}$, absorption coefficient. Annual uptake amount of an element by plants per ha/stock amount of the element in soil pool per ha $(0-30 \mathrm{~cm})$.

${ }^{b} \mathrm{UC}$, utilization coefficient. Annual uptake amount of an element by plants per ha/stock amount of the element in plants per ha.

${ }^{\mathrm{c}} \mathrm{CC}$, cycling coefficient. Annual return rate of an element/annual uptake amount of the element

cling coefficients in Vamleshwar mangrove were considerably lower than Kandelia forests by Lin et al. (1987) which were also reflected by its longer turnover rate.

\section{Conclusions}

Our study fills a gap not only in the regional understanding of nutrient dynamics in these systems but in the general understanding of several seasonally driven mangrove systems. Based on our flux results, nitrogen, phosphorus, and potassium appeared fairly well balanced in terms of annual imports and exports in the present study system. Greater utilization coefficients in this $A$. marina dominated mangrove plantation suggest that it is more efficient in nutrient use and conservation.

\section{Acknowledgements}

Financial support by the Ministry of Environment and Forests (MoEF), New Delhi is gratefully acknowledged.

\section{References}

Akamatsu Y, Ikeda S, Toda Y (2009). Transport of nutrients and organic matter in a mangrove swamp. Estuarine Coastal and Shelf Science 82:233-242.

Alongi DM (1989). The role of soil-bottom benthic communities in tropical mangrove and coral reef ecosystems. Aquatic Sciences 1:243-280.

Alongi DM, Ramanathan AL, Kannan L, Tirendi F, Trott LA, Prasad MBK (2005). Influence of human induced disturbances on benthic microbial metabolism in the Pichavaram mangroves, Vellar-Coleroon estuarine complex, India. Marine Biology 147:1033-1044.

Anuchin NP (1970). Forest Mensuration, second edition. Israel Program for Scientific Translations, Jerusalem, p. 307-339.

Bala Krishna Prasad M, Ramanathan AL (2008). Sedimentary nutrient dynamics in a tropical estuarine mangrove ecosystem. Estuarine Coastal and Shelf Science 80:60-66.

Boto KG (1992). Nutrients and mangroves, p. 63-69. In: Connell DW, Hawker DW (Eds.). Pollution in Tropical Aquatic Systems CRC Press, Boca Raton.

Boto KG, Wellington JT (1983). Nitrogen and phosphorus 
nutritional status of a northern mangrove forest. Marine Ecology Progress Series 11:63-69.

Carlos A, Silva R, Oliveira SR, Rego RDP, Mozeto AA (2007). Dynamics of phosphorus and nitrogen through litter fall and decomposition in a tropical mangrove forest. Marine Environmental Research 64:524-534.

Chen LZ, Lindley DK (1983). Nutrient cycling in Hampsfell bracken grassland ecosystem, England. Acta Botanica Sinica 25:67-74.

Dittmar T, Hertkorn N, Kattner G, Lara RJ (2006). Mangroves, a major source of dissolved organic carbon to the oceans. Global Biogeochemical Cycles 20(1)101-210.

Duvigneaud P, Denaever-De Smet S (1970). Biological cycling of minerals in temperature deciduous forests, p. 199-225. In: Reichle DE (Eds.). Analysis of Temperate Ecosystems Springer-Hague, New York.

Erskine PD, Lamb D, Bristowb M (2006). Tree species diversity and ecosystem function:can tropical multi-species plantations generate greater productivity? Forest Ecology and Management 233:205-210.

Golley FB, McGinnis JT, Clements RG, Child GI, Duever MJ (1975). Mineral Cycling in a Tropical Moist Forest Ecosystem. University of Georgia Press. Athens, Georgia.

Gong WK, Ong JE (1990). Plant biomass and nutrient flux in a managed mangrove forest in Malaysia Estuarine Coastal and Shelf Science 31:519-530.

Islam S, Mchenga S, Tsuchiya M (2008). Nutrient dynamics in mangrove crab burrow sediments subjected to anthropogenic input. Journal of Sea Research 59:103-113.

Kimmins JP (2004). Forest Ecology:A Foundation for Sustainable Forest Management and Environmental Ethics in Forestry. Pearson Education, Inc., NJ.

Komiyama A, OngJE, Poungparn S (2008). Allometry, biomass, and productivity of mangrove forests: A review. Aquatic Botany 89:128-137.

Larcher W (1983). Physiological Plant Ecology. Springer-Verlag, Berlin, p. 50-157.

Lin P, Su L, Lin QY (1987). Studies on the mangrove ecosystem of the Jiulongjiang river estuary in China, II. The accumulation and biological cycle of potassium and sodium elements in the Kandelia candel community. Acta Ecologica Sinica 7:102-110.

Lin P, Zheng WJ (1986). Studies on the increments of two mangrove species, Kandelia candel (L.) Druce and Bruguiera sexangular (Lour.) Poir., in China. Acta Botanica Sinica 28:224-228.

Murphy J, JP Riley (1962). A modified single solution method for the determination of phosphate in natural wastes. Analytica Chimica Acta 27:31-36.

Nirmal Kumar JI, Nirmal Kumar R, Patel K, Bhoi RK (2011). An evaluation of fuelwood properties of some Aravally mountain tree and shrub species of Western India. Biomass 35(1): 411-414.
Nirmal Kumar JI, Nirmal Kumar R, Patel K, Bhoi RK (2010a). An assessment of carbon stock for various land use system in Aravally Mountains, Western India. Mitigation and Adaptation Strategies for Global Change 15(8):811-824.

Nirmal Kumar JI, Nirmal Kumar R, Sajish PR, Bhoi RK(2010b). Wood and Leaf Litter Decomposition and Nutrient Release from Tectona grandis Linn. f. in a Tropical Dry Deciduous Forest of Rajasthan, Western India. Journal of Forest Science 26(1):17-23.

Nirmal Kumar JI, Nirmal Kumar R, Bhoi RK, Patel K (2010c). Seasonal changes of bioelements in the litter and their potential return to green leaves in five species of the Indian tropical dry deciduous forest, Western India. Journal of Forestry Research 21(1):33-38.

Nirmal Kumar JI, Nirmal Kumar R, Patel K, Bhoi RK (2009a). An assessment of Indian fuelwood with regards to properties and environmental impact. Asian Journal of Energy and Environment 10(2):99-107.

Nirmal Kumar JI, Nirmal Kumar R, Bhoi RK, Sajish PR (2009b). Quantification of nutrient content in aboveground biomass of teak plantation in tropical dry deciduous forest of Udaipur, Rajasthan, India. Journal of Forest Science 55(6):251-256.

Prasad MBK (2005). Nutrient dynamics in the Pichavaram mangroves, south east coast of India. PhD thesis. Jawaharlal Nehru University, New Delhi, India, p. 172

Schwartz MW, Brigham CA, Hoeksema JD, Lyons KG, Mills MH, Van Mantgem PJ (2000). Linking biodiversity to ecosystem function:implications for conservation ecology. Oecologia 122:297-305.

Schwendenmann L, Riecke R, Lara RJ (2006). Solute dynamics in a North Brazilian mangrove:the influence of sediment permeability and freshwater input. Wetlands Ecology and Management 14:463-475.

Shaiful AAA (1987). Nitrate reduction in mangrove swamps. Malaysian Applied Biology 16:361-367.

Tam NFY, Li SH, Lan CY, Chen GZ, Li MS, Wong YS (1995). Nutrients and heavy metal contamination of plants and sediments in Futian mangrove forest, p.149-158. In: Wong YS, Tam NFY (Eds). Asia-Pacific Symposium on Mangrove Ecosystems Kluwer Academic Publishers, The Netherlands.

Tomlinson PB (1986). The botany of mangroves. Cambridge University Press, Cambridge. p. 413

Twilley RR, Lugo AE, Patterson-Zucca C (1986). Litter production and turnover in basin mangrove forests in southwest Florida. Ecology 67:670-683.

Uchiyama Y, Nadaoka K, Rolke P, Adachi K, Yagi H (2000). Submarine groundwater discharge into the sea and associated nutrient transport in a sandy beach. Water Resources Research 36:1467-1479.

Wiebe WJ (1987). Nutrient pools and dynamics in tropical marine coastal environments, with special reference to the Caribbean and Indo-West Pacific regions. UNESCO 
56

Reports in Marine Sciences 46:19-42.

Wong YS, Lan CY, Chen GZ (1995). Effect of wastewater discharge on nutrient contamination of mangrove soils and plants, p. 243-254. In: Wong YS, Tam NFY (Eds.). Asia-Pacific Symposium on Mangrove Ecosystems Kluwer Academic Publishers, The Netherlands.

Woodroffe CD, Bardsley KN, Ward PJ, Hanley JR (1988). Production of mangrove litter in a macrotidal embayment, Darwin Harbour, N.T. Australia. Estuarine Coastal and Shelf Science 26:581-598.
Woodwell GM, Whittaker RH, Houghton RA (1975). Nutrient concentrations in plants in the Brookhaven oak-pine forest. Ecology 56:318-332.

YiMing L, Sternberg LSL (2007). Nitrogen and phosphorus dynamics and nutrient resorption of Rhizophora mangle leaves in South Florida, USA. Bulletin of Marine Science 80(1):159-169. 